\title{
Planning a functional city centre in a physiographic constrained landscape: A case study of Lokoja, Nigeria
}

\author{
Simon, R. Funsho ${ }^{1 *}$, Adewale Bukola ${ }^{2}$ and Fulani Omoyeni ${ }^{2}$ \\ ${ }^{1}$ Department of Estate Management, Covenant University, Ota, Ogun State, Nigeria. \\ ${ }^{2}$ Department of Architecture, Covenant University, Ota, Ogun State, Nigeria.
}

Accepted 21 August, 2013

\begin{abstract}
The city centre planning and redevelopment in developing cities, the location, function and physical form of such cities notwithstanding often remain the hardest planning proposal to be accomplished by any planning endeavour. The magnitude of this problem has been linked to the origin and locations of many settlements especially those associated with poor relief environment which later poses numerous planning challenges such as malfunctioning of such cities' central area planning. This study therefore aims at planning a more viable and functional 'city centre' that befit the ever growing and physically distorted Lokoja town which existing central area is currently undermining the physical need of the inhabitants. Moreover, in the face of physical environmental challenge, there must be a good choice of locating a befitting site for its central area development. In the literature, it is evident that there are different concepts worldwide in the development of this centre hence copying from one style of design may not really work else where because of many peculiarities. Methodologically, the study employs detailed land-use studies, traffics survey and other social research analytical tool to propose a better choice of alternative site for the central area development. The researchers conceived a 'pedestrian precinct principle' for the central areas that is being anticipated and concludes that the fiscal resources or funding of the central area plan implementation be sourced possibly from either urban development bank or directly from central government.
\end{abstract}

Key word: City centre, designing, physical terrain, planning.

\section{INTRODUCTION}

Most of the physical planning problems or constraints being experienced today in many developing cities, especially African cities are not absolutely lack of political wills from the government or do they have much to do with expertise, financial or fund diversion to less important societal needs. "Political will from government level to community level is fundamental in the planning, implementation and success of any development programme (UNEP, 2009)

In our many years of planning experience, we have come to a realization that most settlements in those nations, especially in Nigeria hailed from a poor back- ground, the kind that will always make physical planning a hard task to accomplish. For one reason or the other many settlements in Nigeria originated from geographical locations from where such settlements have continued to spread out. Greed (2000) who observed the same trend of cities centres constraint in the United kingdom noted that the 'inner city' has been a major planning issue in recent years and this has been followed by a continuing concern with urban renewal and regeneration of deprived areas. However, beyond the obvious causes of this current challenge, every developmental planner has often considered these as threats to planning exercise. It is in 
the light of this that Jeffrey and Pounder (2004) argued that good physical and environmental condition of a place will always engender the physical regeneration of the spatial place.

Many decades of association of towns with mountains or high relief have been identified with many of such settlements in the south west region of Nigeria; places like Abeokuta, Idanre, are typical examples that are known for their lofty terrain locations. Several other towns took their sources around riverside or by the sea. All these physiographic constraints have been identified as militating against the re-planning and redevelopment efforts in those cities. And much more pathetic is difficulty in getting the indigenous inhabitants to shift base to a better site.

The northern Nigerian cities of Yola, Lokoja and Makurdi are again typical examples where physical planning and development activities are hard to carry out as a result of their waterlogged terrains. The situation of Lokoja became worrisome as the traditional town is inseparately helmed between a flat top mountain range and the Niger River, a condition that has limited the growth of the town.

This study considers the choice of Lokoja as a good case study to showcase the much needed research in strategic methods in planning physically constrained settlements in Nigeria. More importantly is how to create a cognitively strong and functionally meaningful Central area which encourages the visual enhancement of areas adjoining the town.

By intensive and prolonged observations, the authors have realized that Lokoja has the most terrific physical environmental challenges than all other Nigerian towns. First, the two rivers on yearly basis keep launching serious flood from the upsurge of the rivers over the years. Moreover, the mountain range (called mount Patti) has a geographical spread of over $10 \mathrm{~km}$ in length, occupies the major portion of the town land area.

On the basis of authors proposal and definition of central area (city centre) concept, this research recommends a good site for the development of a befitting city centre for Lokoja, (a northern Nigeria town), with the preconceived purpose that the town will become one of the most functioning and viable towns in the region.

In Nigeria, the subject of town centres and their redevelopment become very imperative, especially at this crucial time when many local planning authorities or agencies are being re-awakened to their roles- making the towns function well, and even beyond this is the fact that the combined technological and societal change have continued to offer new challenges which could have a bearing on the way we use our town centres and more particularly the future direction of form and function of town centres in a challenged situation like Lokoja's case.

The current dilemma of developing a viable and functioning central business district (CBD) for Lokoja can be framed through these three choices:

(1) Stay in the existing centre: that is, the way things are now, with many choices with a value-neutral approach to the choice made;

(2) Locate an sufficiently accessible site for the centre development: focusing on reducing congestion at the city centre; and

(3) Connect all the adjoining neighbourhoods with local shopping centres: focusing on intra-neighbourhood transit enhancement for residents, emphasizing short trips along all major transport routes especially the Felele main artery.

\section{REVIEWED LITERATURE}

The centre of the city is known variously as the city centre, 'town centre', 'central district zone'. central business district (CBD), core area and inner city. In most Americans literatures and usage the CBD is simply described as 'down town' (Kenneth, 1978). For clarity and meaning, this central area is referred to as that complex of activities- shopping, office, cultural, administrative, entertainment, wholesaling, industrial and any engulfed residential enclave which characterized the landuse pattern of the innermost area of towns, and is usually quite clearly differentiated from more homogenous tracts of housing and industry on its borders. In his definition, Lewis (1976) defines the central areas of British town as "the part of the town in which the central services of the highest order which the particular types of town can support are found".

While most descriptions of central areas have been based on centrality and location attributes, Murphy and Vance (1954) who are researchers in the field of urbanization have defined the CBD as "an area where essential functions appeared to be the retailing of goods and services for a profit". It is pertinent however to know that these definitions do not apply wholly to all category of central areas especially those of the developing cities. In other words, an exact definition of the central area which can be applied to more than one city has not yet been evolved but key words as: certain services of the highest order, service which are used by the population of the town as a whole tend to characterized definition of central areas of the developed countries.

Town centre in brief is a whole spiral of activities that are location specific within the city setting of which retailing and whole selling are prominent. Town centre is far more than a shopping centre, but much more. Yvonne(1998) has described this city segment as a place that is more of a mixed use and of intense interaction with which the life of the whole town is involved, and which reflects the quintessential essence of that town, giving it identity, image and hopefully, civic pride. Greed (2000) reiterates the fact that the 'inner city' has been a major 
planning issue in recent years and this has been followed by a continuing concern with urban renewal and regeneration of deprived areas.

Principally, town centres are areas of intensive mixed use where most of the activities within the town interact in some ways. As such, the town centre acts as a central reference point for a town, giving it identity and image. In most developing countries including Nigeria, attempts have been made to precisely define and delineate the central areas, in conformity with the local standard of planning. To this effect, Frederick (1959) sees the central area of old town as consisting of dominant buildings (a cathedral, a palace or a castle) and a dominant civic space. Nigerian town centres have taken another dimension in formation lately. We now have a dual town/city centres in a town, that the existence of a traditional and modern town centre, dispensing almost the same roles to the diverse population of the town. Usually, the market square often formed the nucleus of the town. The concepts become clearer only as they apply to the two extremes of the continuum, that is, to the developed and underdeveloped countries. While the former may be at the verge of understanding the benefits of planning this very centre of activities, the later often focus on its improvement, regeneration and expansion with diversity of policies or programmes and schemes. Experience of some cities in America reveals that the first 25 years of transit-related development in DC (District of Columbia) was focused on the core of the city, that is, the central business district which has expanded outward from inner town and touches some of the neighbourhoods around the core. However, in the last eight years transit-oriented development has moved out of the core to neighbourhoods like Columbia Heights, Petworth, etc (RPIUS, 2013)

Furthermore, the current challenge for local authorities in most developing nations is to be able to respond quickly and appropriately to numerous challenges within the statutory framework, enabling town centres to adapt, survive and indeed thrive as vital and viable centres in accordance with the spirit of good governance and the interests of achieving a more sustainable pattern of development (Yvonne, 1998). Many city or town centres have suffered from lack of coherency, strategic planning and poor investment, consequently such centres soon loss their civic pride. But the key to successful physical regeneration is to understand the constraints and the potential of the existing physical stock and the role improvement can play in enabling, and where appropriate promoting, renewal at urban or neighbourhood level (Robert and Sykes, 2004).

Many past studies on city centres issues including harems challenges provide a useful appendage to planning practice on how to re-assess individual town centres, check their health and devise a strategy for solving the challenge. It must be realized that just as every material element responds to its enforcing agent, so also the change that is already compelling less developed town/city centres to change in the right direction is becoming real. Now, a new order to birth change may come through any of these objectives of city centre rejuvenation: creating a multi-functional city core that has diverse land uses and attracts a broad range of visitors and reinforcing the importance of city centre as a center for commercial activities, a hub for vehicular movement, and a hub for other services.

\section{Concept of central area designs}

Central area designs often vary in shape and sizes. Some are compact in form while others appear loose in coordination. However, central area design concepts illuminate researchers understanding of the varied designs option that can be adopted in any given place according to planning principles (Keebles, 1976).

\section{Central area within city traffic}

This is the most common kind of centres which often develop along traffic routes and in most cases unplanned. The problems with this type include: enormous chaotic traffic, lack of parking spaces, lack of proper delivery points, traffic hold-ups. This could be called an incidental central area.

\section{Central area at traffic routes}

This centre develops along traffic routes, problems of lack of organization and improper utilization of land uses are visible.

\section{Central area at traffic junction}

The central traffic junction becomes a square while areas bounding it consist of shopping centres. The problem with this is that visitors park along the routes. Although most deliveries are done at the backyard of the shops, it is not convenient for trucks to turn easily. Pedestrians crossing could pose a danger. However, this kind of centres is tightly built and compact. The relative shopping distances are reduced to minimum.

\section{Pedestrian precinct with parking enclosed by ring road}

Here, the vehicular traffic is completely separated from the pedestrian traffic. It offers the pedestrians the opportunity to shop round without bordering to think of crossing a vehicular traffic way. This concept like others, 
poses some problems, noticeable among them is that of servicing the shop with goods. The peaceful shopping pedestrian's zone could further be enhanced by integrating squares and playing ground within the centre to make it more fascinating.

\section{Pedestrian precinct with parking enclosed by centre}

In a more critical observation, Lokoja town's proposed central area site, wholesomely depicts attributes of a central area that is situated along traffic routes or within the town traffic. For that reason and in view of the problem associated with such design, it should be discouraged. The actual plan for the town's Central Business District is to become a pedestrianized centre.

Against this backdrop, this study has developed an evaluation method to select the most functional and adoptable concept that would harmoniously integrate with the existing sites/situation

\section{RESEARCH METHOD}

Some planning and social sciences methods have been employed in this study, including Strength, Weakness, Opportunity, Threat (SWOT) analysis which was engaged to help in identifying all positive and negative attributes that are embedded inside the alternative sites selected for the town centre's development. This involves a critical evaluation of alternative city centre sites in terms of its physical strength, weakness and opportunities attributes all with one goal to transform the economy of the town. In addition, the work engages the tool of traffic survey (both origin-destination and volume) to its fullness while actual measurements of urban elements were carried out. Traffic survey carried out was to determine the vehicular volume as well as origin and destination of the traffic around the city centre. Basically, a 12-h (6.30am $6.30 \mathrm{pm})$ traffic volume survey was conducted within the town in three stations or recording points and were conducted basically in three selected days: a typical working day (monday); a regional market day (falls on tuesday) and during a weekend (Saturday). See Appendix 1 for details data. Based on the town vehicular movement in and outside the proposed central area, the three stations were selected randomly. And these include:

1. A point around the Paparanda Square along the road leading to Crowther Memorial College.

2. A location opposite the state House of Assembly, along Murtala way.

3. A point along the road linking Lokoja traditional core and the new layout.

The survey (volume count) on all the three stations included all types of vehicles categories under five (5) broad groups based on their passenger car unit (p.c.u) value as: (a) Car, taxi, mini-bus and light van $=1.00$, (b)tractor, trunks $=2.00$, (c) Buses (large) trailer $=3.00$, (d) motorcycles $=0.75$, (e) bicycles $=0.30$.

\section{BACKGROUND OF LOKOJA AND FUTURE PHYSICAL DEVELOPMENT}

Administratively, Lokoja is the capital city of Kogi State (Nigeria). The ancient town lies between latitudes $7^{\circ} 45^{\prime} \mathrm{N}$ and longitude $6^{\circ} 45^{\prime} \mathrm{E}$ and can simply be called a gateway town to the northern Nigeria, especially to the Nigerian Federal Capital city of Abuja. Location-wise, Lokoja is unique for two reasons: first, it is well linked and accessible through both state and federal highways. Second, its location is at the confluence of the River Niger and Benue and a massive flat topped ridges (mount Patti) which put the town at a serious disadvantage for physical expansion; the two barriers of the water body and the ridges had streamlined the settlement to a linear one and has a modifying effect on the climate (Alabi, 2009)

Focusing on development, the physical attributes of Lokoja has been the main concern, in other words, there is need for strategic and workable plans for the future growth of the town, especially the siting of the town centre within the present town structure.

The surveys of the Lokoja's physiographic landscape have revealed that only less than $60 \%$ of the town's landscape can be built upon in view of many dissected terrains of the town. In other words, the shape and overall disposition of the town varies in many ways because of the ruggedness of the topography (Figure 2).

\section{Lokoja Town Structure and Growth Direction}

Like any other organised entity, a city or town can be analysed from two angles, one revealing its structure (anatomy) and the other its operation (physiology). A town's structure is the spatial pattern of its differentiated parts and functions, and its physiology is the interchange that occurs between these specialized units (Kingsley, 1954).

\section{Alternative A}

This is a linear development to the south of the existing town along the River Niger and extending south-west wards. As shown in Figure 1a, Lokoja town is shaped like a triangle with the River Niger as its base. The bypass to the north follows the south side of the Patti Ridge to form the north western boundary of the town and join the proposed coastal road which extends to the south, crossing the river Mimi and heading towards the proposed 


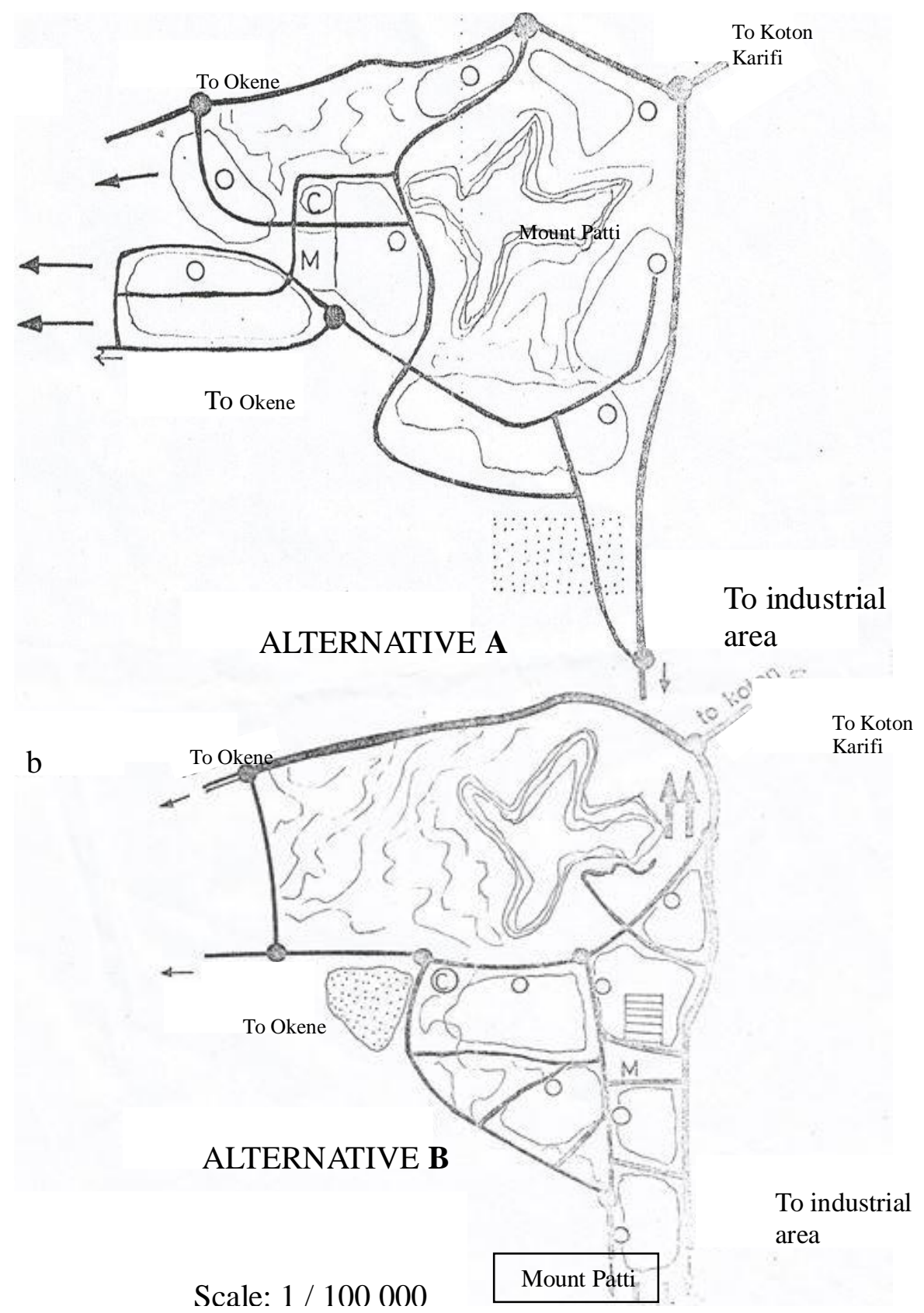

Figure 1. Alternatives Lokoja town structure and growth direction. Source: Dalal (1994). Lokoja Master Plan (1974 - 2005).

proposed ferry terminal apron at Ganaja and the Industrial zone at the southern end of the town.

The area surrounding Mimi River was initially proposed by the town's master plan about three decades ago as a green area alongside with the alternative town centre.

\section{Alternative B}

As shown in Figure 1b, there is also a linear development orientation mainly to the west of the Patti Ridge: This alternative takes the old Kabba-Lokoja road as the major impetus of growth. Not only is the town adequately protected from the Hamanttan winds which blow from the north east direction of the town, it is also favourably exposed to the cooling south westerly winds. The residential development does not cross River Mini, as the area has been exclusively reserved for government's use. The existing long road in the area is actually fed at intervals from the old Kabba-Lokoja road and from a new 

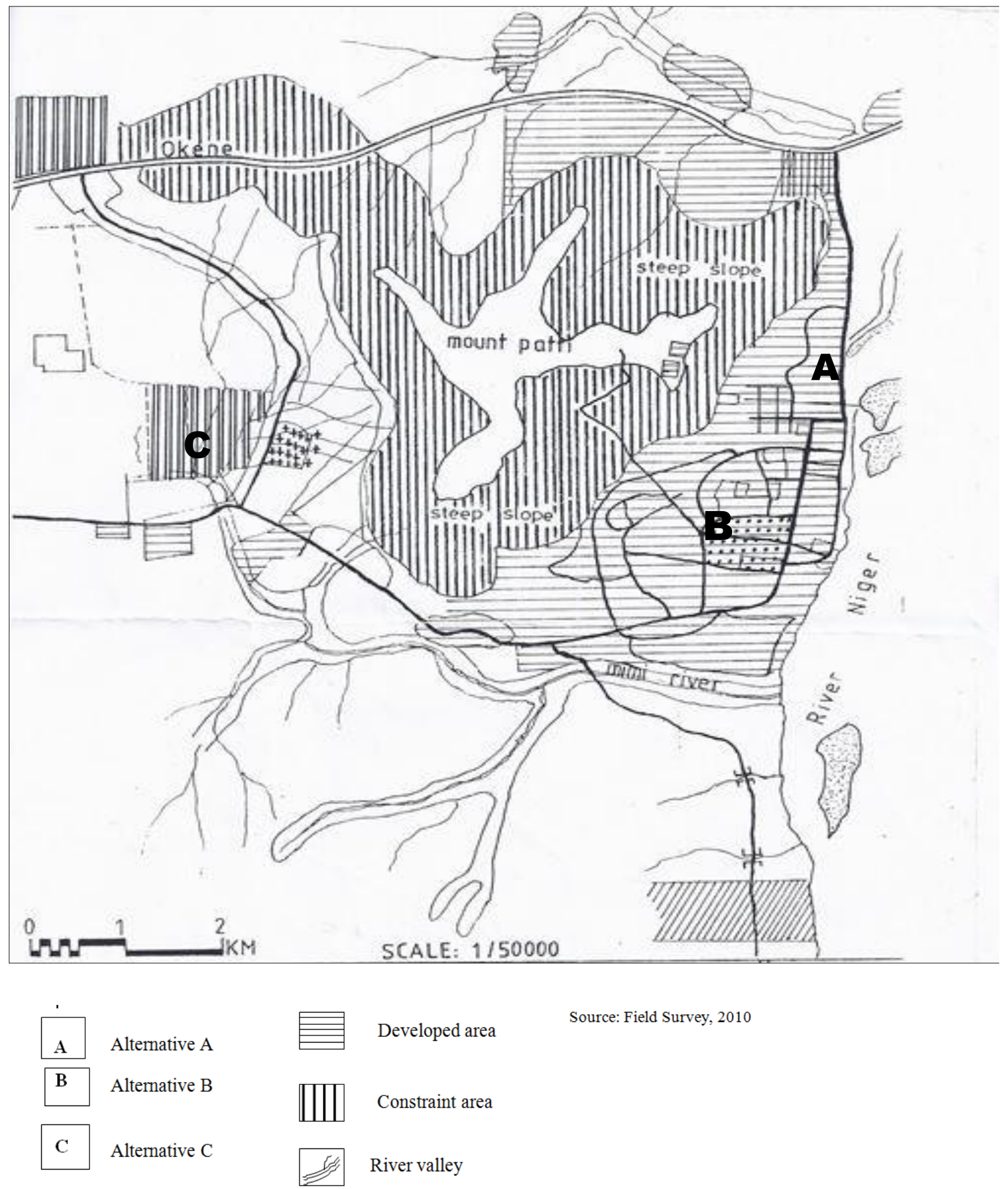

Figure 2. Alternative central sites for Lokoja.

bypass road. It is however pertinent to note that development of Lokoja has actually been patterned after these two alternatives as proposed by the 1974 Master plan.
Today, colossus physical development has taken place along the southern direction, and the south-west of Lokoja. Both state government residential low cost 
Table 1. Factors peculiar to the sites

\begin{tabular}{|c|c|c|c|c|}
\hline $\mathbf{S} / \mathbf{N}$ & Criteria employed & ALT 'A' Site & ALT 'B' Site & ALT 'C' Site \\
\hline 1 & Form of site Rating & $\begin{array}{l}\text { Flexibility The old central } \\
\text { area is handicapped by } \\
\text { lack of space (poor) }\end{array}$ & $\begin{array}{l}\text { Can be improved to } \\
\text { accommodate all the } \\
\text { functions expected of the } \\
\text { central area. (good) }\end{array}$ & $\begin{array}{l}\text { Being a virgin site, it can contain all } \\
\text { functions adequately. (Good) }\end{array}$ \\
\hline 2 & $\begin{array}{l}\text { ¿Economic (cost of } \\
\text { development ) }\end{array}$ & $\begin{array}{l}\text { Although already } \\
\text { developed, but not with } \\
\text { adequate facilities. } \\
\text { Destruction of residence } \\
\text { blocks will be high (Fair) }\end{array}$ & $\begin{array}{l}\text { Existing functions that can } \\
\text { be integrated in the centre } \\
\text { are already available. The } \\
\text { cost will be very low. (good) }\end{array}$ & $\begin{array}{l}\text { A vacant site of this nature requires } \\
\text { new facilities and utilities. Cost is } \\
\text { expected to be very high. (poor) }\end{array}$ \\
\hline 3 & $\begin{array}{l}\text { Rating Government } \\
\text { policy }\end{array}$ & $\begin{array}{l}\text { Not the plan but merely } \\
\text { to improve the site. } \\
\text { (poor) }\end{array}$ & $\begin{array}{l}\text { Government's in tension to } \\
\text { remain is not convincing. } \\
\text { (poor) }\end{array}$ & $\begin{array}{l}\text { Government's movement to the site is } \\
\text { highly rated. (Good) }\end{array}$ \\
\hline $4 a$ & $\begin{array}{l}\text { Decision to stay in } \\
\text { site) } \\
\text { rating performance } \\
\text { (short- Rating) }\end{array}$ & $\begin{array}{l}\text { Short - run performance } \\
\text { is fair because of low } \\
\text { competition (Fair) }\end{array}$ & $\begin{array}{l}\text { Expected to yield results } \\
\text { having the ability to } \\
\text { integrate both the old and } \\
\text { the new development of } \\
\text { Lokoja. (Good) }\end{array}$ & $\begin{array}{l}\text { Performance is low. Economy return is } \\
\text { handicapped in the short run. (poor) }\end{array}$ \\
\hline $4 b$ & $\begin{array}{l}\text { Performance (Long } \\
\text {-run) }\end{array}$ & $\begin{array}{l}\text { Performance depended } \\
\text { solely on the choice of } \\
\text { Alt. B or 'C' and } \\
\text { population growth. } \\
\text { (poor) }\end{array}$ & $\begin{array}{l}\text { May be very high if the } \\
\text { town continues to develop } \\
\text { in different direction } \\
\text { sectorially. (Fair) }\end{array}$ & $\begin{array}{l}\text { Provided that population and adequate } \\
\text { public facilities are provided the site is } \\
\text { promising. (Good) }\end{array}$ \\
\hline
\end{tabular}

Source: Field survey, 2010.

estates and private individual development have been planted. It is on this basis of physical expansion that sites selection for the anticipated central area will be based.

\section{DATA ANALYSIS AND DISCUSSION OF FINDINGS}

The classification counts carried out by traffic mode are graphically represented by charts as shown in Appendix 1. The total traffic volume according to mode in all the stations indicated that motor-cycle (pcu.075) is a very common mode of transport in Lokoja having constituted the largest volume in almost all the counting points. This is followed by car, taxi and then light buses (pcu 1) (Table 1). On a general note, the largest traffic counts were recorded on Monday and the least on Saturday. Tuesday traffic is being influenced by the regional market which coincides with the sampled day of the traffic count. The traffic along Lokogoma, toward the proposed town centre is highest on Monday. This is expected hailing from the fact that majority of government workers reside in the new layout at Lokogoma and few numbers in Army barrack all in the same direction.

Again on Tuesday traffic is heaviest along Murtala road- the only major road that passes through the town. The total traffic of 30,583 and 29,918 were taken in point $A$ and $B$, respectively. These figures are envisaged since large numbers of vehicles from other parts of the state have to pass through the road before getting to the market.

The Origin-Destination Survey was conducted at the three (3) stations which also run simultaneously with the traffic volume count. Basically, the survey was planned for internal movement pattern which assist in getting the volume of traffic to a particular destination and into the proposed central area. Secondary data came from government offices such as national population census offices (1999) and works department of the State ministry of Urban Planning.

Generally, the traffic flow pattern of Lokoja town according to the survey carried out is a confirmation of the irregularity of traffic distribution on the town major and access roads. The over congestion of traffic along Murtala way suggests a need for swift government intervention on the town traffic, through a diversion which could be either by absolute construction of more access roads or by-passes. The effective functioning of the town centre anticipated depends solely on the reduction of the traffic congestion along Murtala way to the minimum level.

\section{Evaluation of Lokoja central area alternative sites}

With the application of a simple random sampling technique three (3) sites were selected for Lokoja City Centres development. These include: 
Table 2. Scoring of alternatives.

\begin{tabular}{|c|c|c|c|c|}
\hline 1 & $\begin{array}{l}\text { Factors peculiar to the whole } \\
\text { urban systems. }\end{array}$ & ALT 'A' & ALT 'B' & $A L T$ ' $C$ ' \\
\hline \multirow[t]{2}{*}{2} & $\begin{array}{l}\text { Factors vis-a-vis the whole urban } \\
\text { system. }\end{array}$ & 2.5 & 7 & 3.5 \\
\hline & Total Score & 0.53 & 2.59 .5 & $2.5=6$ \\
\hline
\end{tabular}

Grading: Good $=1$, fair $=1.5$, poor $=0$.

1. The existing traditional central area (Alternative ' $A$ ')

2. The site around the governor's office ("B')

3. The old master plan (1974) proposed site (" 'C')

Reliability and confidence of choice was further enabled through employment of SWOT technique which basically is an acronym name for Strength, Weakness, Opportunity, and Threat. The engagement of SWOT is to help identify and analyse all positive and negative attributes that are embedded inside the alternative sites selected for the city centre proposal.

The various alternative sites are shown in Figure 2. For the purpose of analysing these sites, two objectives were set up: First, to identify the traits/characters that are peculiar to the sites themselves. Second, to ascertain the degree of association between each site and the various dimensions of the town development. However, the rating of the alternatives sites are achieved by intensive appropriation of four criteria presented in Table 1 and summarized result in Table 2.

From the two score tables (Tables 1 and 2), it is distinctively cleared that site ' $\mathrm{B}$ ', that is, area around the present Governor office is far better than other proposed sites.

At this level of analysis, all the factors used were made to carry the same load (weight), nevertheless it is pertinent to stretch further two major contending factors about Lokoja future physical development. These are: Fiscal resources capability and the issue of centrality in locating certain functions.

\section{Fiscal resource capability}

The development of Lokoja town and its CBD will solely depend on the financial capability of the state government, both to induce industrial development and to improve the stained landscape of the town itself. It is envisaged that the physical development of the town will be mostly hindered by the poor topography- range of ridges, valleys and water bodies which have put the whole urban landscape into a dissected fragments. For this cause and particularly for the purpose of implementing any physical development plan of the town, a planning strategy is required. Much financial commitment would be needed to put the landscape in the right order before any meaningful development can commence. Under the present poor financial stance of the state government, no significant development can be expected.

At the moment, a strong financial support will be required to carry out lots of infilling and earth-grading of each segmented part of Lokoja town. All these may have justified the choice of alternative ' $\mathrm{B}$ ' as the most financially viable site of the anticipated central area development for the town, as it is relatively cheaper to develop an already built site than to develop a virgin land.

\section{Centrality of activities location}

The irregularities of Lokoja urban landscape resulting from existence of lofty ridges, valleys and river bodies can help resolve the predicament of the service centre location. An examination of the needs and potentialities of each segmented part or area is an essential basis for the selection of future development of Lokoja. In this direction, the town is demarcated, on the basis of its physical separation, into functional types. It is the characteristic of this type of demarcation that Lokoja central area physical development may not be absolutely related to centrality, nonetheless, it is being predicted that such sectional differentiation will bring a healthy balance to the town and support a functional work-rest relationship or an overall performance of the urban system. Type of functions and their proposed locations are depicted in Table 3.

This pattern of activities distribution throughout the town's sectors goes a long way to invalidate the issue of centrality especially the concept of agglomerating all uses in one place. The foregoing discussion of a particular problem area illustrates two important principle of planning, that is:

1. Major functions (activities) should not be proposed for one segmented part without considering the effects they will have on the system of relationships among the whole town.

2. Secondly proposal for new major functions should take full account of projected economic and physical development- both provide additional population and income to support new location. It is of utmost necessity that the centre should combine basic and essential functions. 
Table 3. Location of some functions.

\begin{tabular}{ll}
\hline Type of function & Possible location \\
\hline Administrative functional & Lokoja South-west axis Northern Axis Mid-S/west. Southern, \\
Major commercial (markets) & south-west \\
Industrial & South-west axis \\
Tertiary Institutions & Adonokolo (south-central) \\
Central Area & \\
\hline
\end{tabular}

\section{Recommendation and conclusion}

Implementation management strategies of planning schemes have been a serious obstacle confronting governments of developing world. Successful realisation of the potential site to be developed will require an implementation strategy which recognises and take advantage of the changes under way in economic and social activity, funding regimes, policy and emerging visions of the urban life.

In most developed cities, CBD administration is usually isolated from the generally known city administration, in which case, the agencies responsible for the administration of the central area are autonomous and have little or no interference with the supposedly town planning authority. This system was found to be very effective in Central Area development and enable a non division of attention in such development.

The system which seems to be generally accepted or rather in use in developing countries especially here in Nigeria is that the planning set-up control the physical development at all levels. In the act of town and countries planning, the administrative set up of physical planning implementation cuts across every section or level of planning. In order to implement such plan as this, the Nigerian government at various levels has instituted physical planning boards to monitor such implementation and the sequential growth of their cities. No such separate administration has been instituted purposely for central area. Development of central area has never been given any serious consideration. This laxity has been justified by government nonchalant attitude toward central area development.

Lokoja Central Area development can be phased in a way that it will be implemented over a period of four (4) years. In view of the uncertainty or limited financial backing that could be enjoyed in developing countries through this medium, combination of the following sources of finance have been suggested for the central area development: Loans: Land development of this type should be financed, at least in its initial stages by some types of loan. From the point of view of what a central area ought to be, that is, offering central services to the city populace and its environs or as an organic nucleus which alone can give cohesion to the community; it becomes necessary we plan central areas, in a more realistic ways. Plan must not only be steered but must also be monitored to a successful implementation. Ideally, developing cities should be planning toward decentralisation of certain central area functions so that the central business area can suit the convenience of the society at large. Experience has shown that separated uses can make sense in some situations. Unless this is done, some good central business districts designs may remain mere figures of their original intention.

Conclusively, this work has not only drawn our attention towards the intricacy of orthodox central area planning approaches but on a more important note, it is a whole revelation of the need for a new order: that is, the strategy of decentralization of activities whose presence is seriously jeopardising the whole essence of central area planning. And for physically dissected cities, this promises to work more effectively. It is therefore advised that the social and aesthetic reasons of the centre development should not be traded off for economic benefit. This Lokoja Central Areas planning should be a reference piece for all researchers in urban planning and design.

\section{REFERENCES}

Alabi MO (2009). Urban Sprawl, Pattern and Measurement in Lokoja, Nigeria. Theor. Empir. Res. Urban Manage. 4:13.

Census (1991). National population commission, Lokoja.

Dalal H (1974)._Lokoja master plan (1974-2005).

Frederick G (1959). Town Design. The architectural press, London.

Jeffrey $P$, Pounder J (2004). Physical and environmental aspect in Urban Regeneration a Handbook edited by Robert, P \& Sykes, H. Sage publication, Delhi, 2004.

Kenneth H. (1978). Downtown USA: Urban design in nine America cities. The Architectural press, London.

Kingsley Davis (1954). Cities: Their origin, Growth and Human impact. Reading from scientific America. University of California Berk.

Lewis K (1976). Principles and practice of town and country planning. 153-213. Estate Gez. Ltd, London.

Murphy RE, Vance Jr. JE (1954). Delimiting the CBD. Econ. Geogr. 30. 189-222.

Robert P, Sykes H (2004). Urban Regeneration A Handbook. Sage publication, Delhi.

RPIUS (2013). Web posted article in Rebuilding Place in the Urban Space. Cited in July $24^{\text {th }} 2013$.

UNEP (2009). The Sustainable Cities Programe In Zambia (1994 2007): Addressing Challenges of Rapid Urbanization:

Yvonne AP (1998). Vital and Viable Town Centres, Meeting the Challenge in DOE (1994) research publication. 
Appendix 1. Traffic volume survey of Lokoja on 3 peculiar days.

\begin{tabular}{lccccccccc}
\hline \multirow{2}{*}{ Mode } & \multicolumn{3}{c}{ Monday } & \multicolumn{4}{c}{ Tuesday } & \multicolumn{3}{c}{ Saturday } \\
\cline { 2 - 10 } & A & B & C & A & B & C & A & B & C \\
\hline Car/Bus & 10,062 & 8,522 & 1,970 & 1,153 & 7,198 & 1,468 & 7,971 & 6,067 & 1,679 \\
Tractor & 11 & 97 & 78 & 31 & 62 & 83 & 105 & 17 & 16 \\
Large Bus & 494 & 19 & 13 & 390 & 97 & 18 & 155 & 14 & 47 \\
Motor Cycle & 19,830 & 21,164 & 5,691 & 16,459 & 12,660 & 6,509 & 12,634 & 11,450 & 4,764 \\
Bicycle & 186 & 116 & 150 & 152 & 131 & 101 & 141 & 125 & 75 \\
Total & 30,583 & 29,918 & 7,902 & 18,185 & 20,148 & 8,179 & 21,006 & 17,673 & 6,581 \\
\hline
\end{tabular}

Source: Field survey, March 2010. 